\title{
病理組織学的に診断困難であった 小脳䯣膜腫の晚期肺転移の一切除例
}

\section{Late Pulmonary Metastases of Cerebellar Meningioma-A Case Report}

小川明孝・土井 修・児玉 憲・龍田眞行・宝来 威*・建石竜平**

\begin{abstract}
要旨：患者は61歳の女性で，右側胸部痛を主訴として来院した。19年前に小脳多発性髄膜腫て 摘出術を受けている。胸部X線写真で両側下肺野及び左肺門部に腫瘤影を認めた。胸骨 正中切開下に両側肺より 4 個の腫瘍を摘出した結果，血管外皮細胞腫と組織診断された. しかし，19年前の小脳髄膜腫(fibroblastic)の一部に血管外皮細胞腫様の組織像が認めら れ，それとの類似から今回のものは極めて稀な晚期肺転移と考えられた。
\end{abstract}

〔肺癌 28(6) : 797 803, 1988〕

Key words : Angioblastic meningioma, Pulmonary metastasis, Late metastasis.

\section{症 例}

患者：61歳, 女性

主訴：右側胸部痛

家族歴：父が胃癌で死亡

既往歴：1967年 (42歳時) に小脳多発性骵膜腫 (良性)にて摘出手術を受汁ている.

現病歴：1986年 1 月右側胸部痛が出現. 近医 を受診し，胸部異常影を指摘され，精査目的の ため当センターを紹介された。

大院時所見：前回開頭手術後, 右外側半盲あ り。表在リンパ節は触知しなかった。赤沈 42 $\mathrm{mm} / 1 \mathrm{hr}, \operatorname{CRP} 2(+), \mathrm{CEA} 7.0 \mathrm{ng} / \mathrm{ml}$, ᄀェ リチン $354 \mathrm{ng} / \mathrm{ml}$ 以外血液検査所芫に異常がな かった。

胸部X線所見：左肺底部に境界鮮明な $4.5 \times$ $4.0 \mathrm{~cm}$ の腫瘤影を認女た。一方右肺底部にも $2.0 \times 1.5 \mathrm{~cm} の$ 比較的境界明瞭なっッチを伴っ

$\begin{array}{ccr} & \text { 大阪府立成人病センター外科 } \\ * & \text { * 同 } & \text { 内科 } \\ & \text { 同 } & \text { 病理 }\end{array}$

た小腫瘤影を認めた。さらに左肺門部にも $3.0 \times$ $2.0 \mathrm{~cm} の$ 比較的境界明瞭な分葉した腫瘤影を認 めた (Fig. 1).

Fig. 1. Posteroanterior roentgenogram demonstrates a sharply defined mass in the left lower lung field and well defined masses in the left hilum and the.right lower lung field.

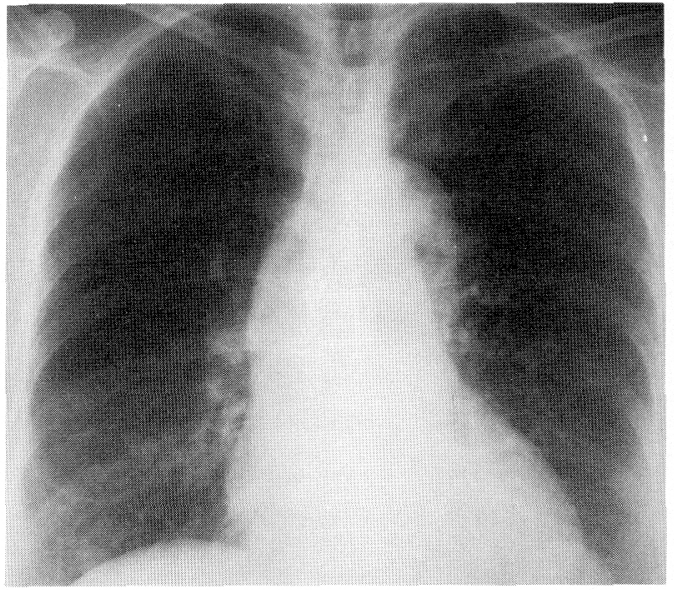


Fig. 2. Computerized tomograms demonstrate sharply defined masses. a) Round mass in the left lower lobe. b) Lobulated mass in the left upper lobe. c) Oval nodule in the right lower lobe.

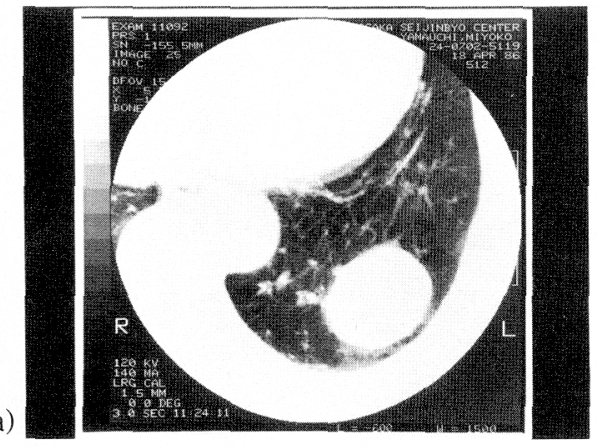

b)

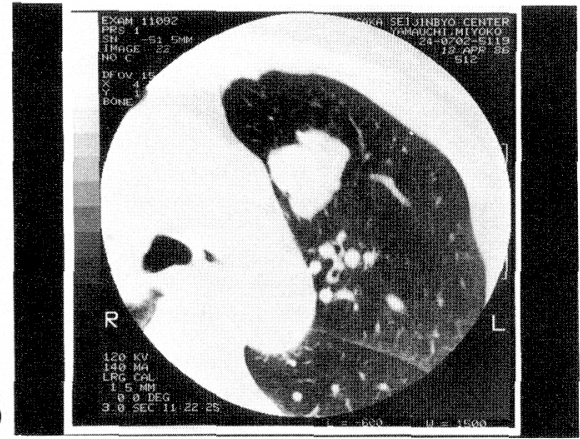

c)

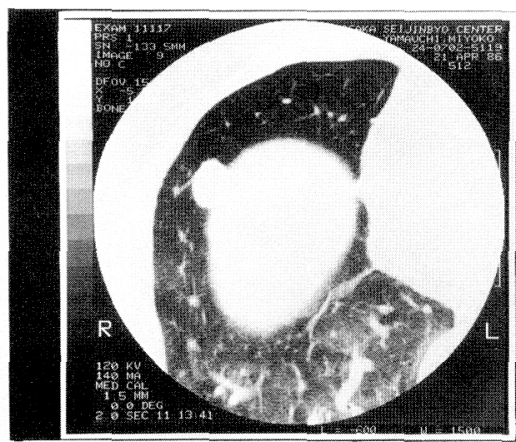

胸部CT所見：Fig. 2a，b扝よびcに胸部X線 写真と一致して 3 つ腫瘍像が認女られた。左 肺門部 $\mathrm{B}^{3} \mathrm{~b} の$ 腫瘍と両側下肺野の腫瘍は境界明 瞭で, 内部は共に立実性かつ均質であり, 血管・

気管支影の収束像や胸膜陷入像は伴っていなか った。

気管支鏡所兒：可視範囲に異常はなかったが， 透視下擦過細胞診で左一 $\mathrm{B}^{10}$ より異型細胞が得
Fig. 3. Cytologic specimen demonstrates atypical cells.

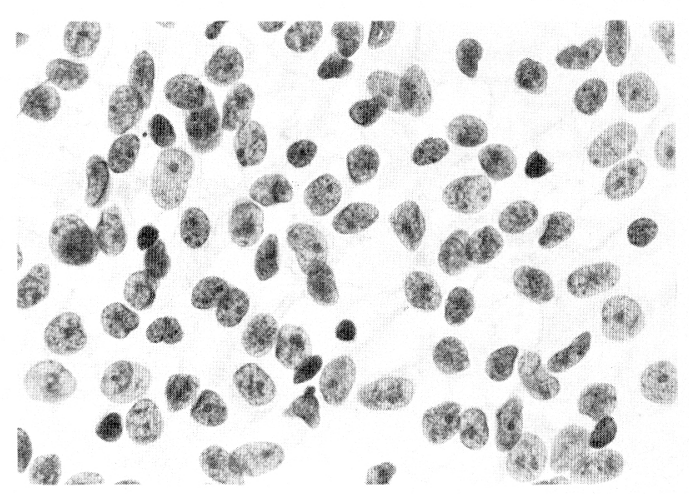

Fig. 4. Histological view of the lung tumor demonstrates metastatic cellular meningioma with dilated vessels.

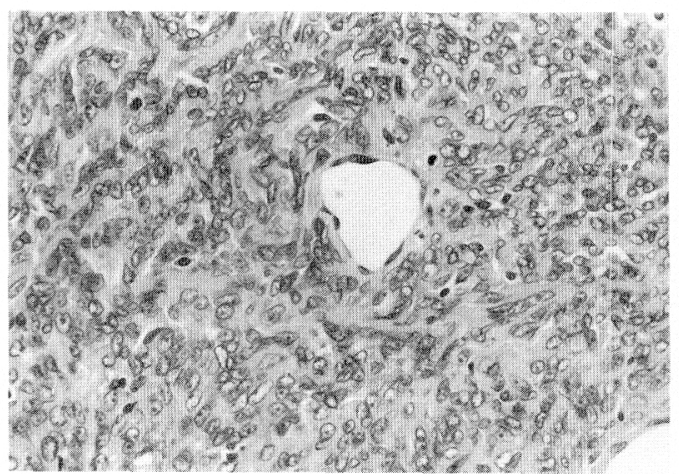

られた Fig. 3)。しかし分類不能腫瘍であり，原 発巣としては腺癌, カルチノイド, 硬化性血管 腫などが考えられた。左一 $\mathrm{B}^{3} \mathrm{~b} か ら の$ 細胞診は 陰性であった。

悪性の可能性が高いこと，3つの腫瘍が必ず しも一元的と断定出来ないこと, 肺以外の臟器 に病変が認められないことなどの理由から， 1986年4月24日手術を施行した。

手術所見：手術は両側肺の腫瘍を切除検索す るため，胸骨正中切開下に行った。左一 $\mathrm{B}^{10}$, 左 一 $\mathrm{B}^{3}$, 右一 $\mathrm{B}^{8}$ の腫瘍および画像上描出されなか った右一 $\mathrm{B}^{1}$ の微小な腫瘍を摘出した。腫疼は実 質性で境界鮮明であったが，血行に富み，易出 血性であった。割面は共に黄白色であった。術 中迅速組織診では，全ての腫瘍は同一組織から 
Fig. 5. Histological views of the cerebellar meningioma ( $\mathrm{H} \& \mathrm{E}$ stain). a) The fibroblastic type component consisting of spindleshaped cells. b) The angioblastic type component showing a large number of thinwalled blood vessels.
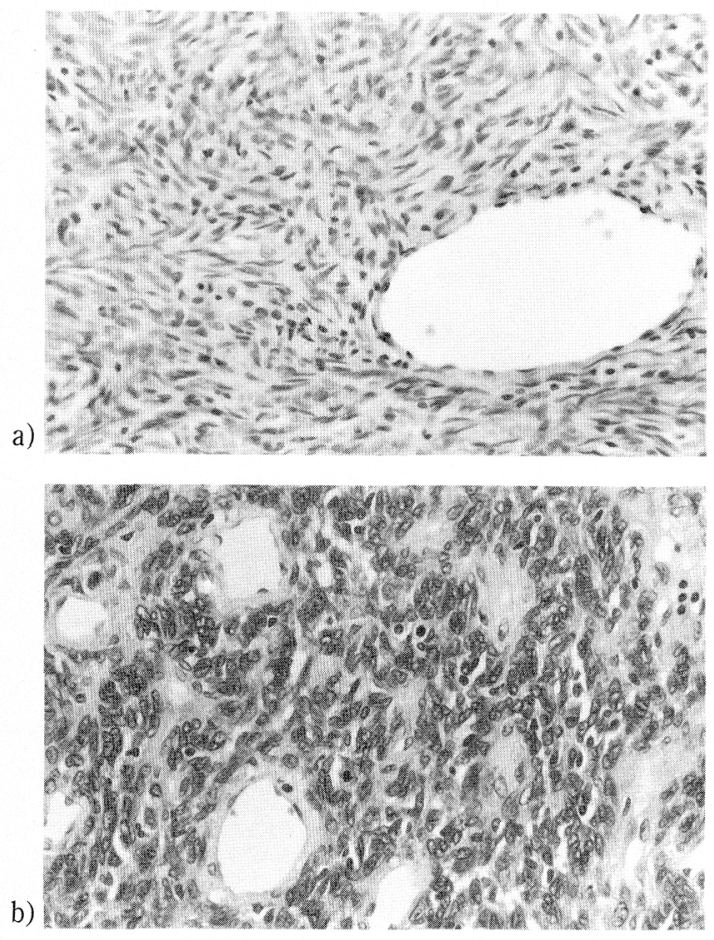

成り，一元的なものと考えられ，血管原性の悪 性腫瘍が強く疑われた。しかし多発性か転移性 かの鑑別は不可能であった。

病理組織学的所見：H\&E染色(Fig. 4)では 腫瘍は全体的に細胞密度が高く, 膠原線維の形 成も著明であった。個々の腫瘍細胞は核が類円 形女るいは紡錘形で，比較的クロマチンに乏し く, 明瞭な核小体を有し, 核の異型性も認めら れた。また所々に核分裂像が認められた。腫瘍 内には非腫瘍性の内皮細胞で内張りされた拡張 性類洞様の小血管が認女られた。病理組織学的 には血管外皮細胞腫と診断されたが，血管外皮 細胞腫がこの様に肺に多発する報告は少なく， 転移も考之られた。

ところが幸いにも19年前の小脳髄膜腫の病理 組織標本と詳細な資料1を入手することが出来 た。その腫瘍の大部分がfibroblastic menin-
Fig. 6. Silver impregnation demonstrates an abundant network of reticulin fibers around the tumor cells and blood vessels. a) From the cerebellar tumor. b) From the lung tumor.
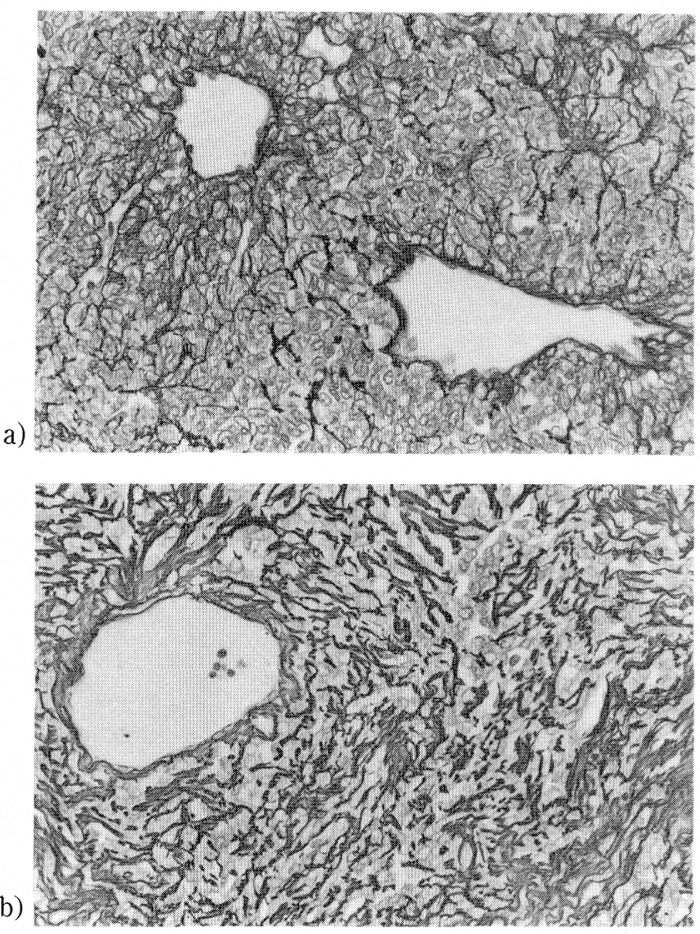

giomaの像 (Fig. 5a) を示していたが, ごく一部 に血管外皮細胞腫様の組織像が含まれていた。 その部分のH\&E染色所見 (Fig. 5b) や鍍銀所見 (Fig. 6a)は今回のもの (Fig. 4, 6b) と類似して おりり，最終的に小脳多発性髄膜腫の晚期肺転移 と診断した。

術後経過：経過良好で術後21日目に退院した。 退院時に頭部CTスキャンも併せ行ったが, 頭蓋 内での再発は認められなかった。術後 1 年 4 力 月の現在健在である。

\section{考按}

本症例は胸部痛を主訴として来院し, 胸部 X 線写真で両肺野に多発する腫瘤影を認め, 転移 性肺腫瘍を強く疑った。しかし術前の諸検査で 原発巣を確定し得ず，病巣擦過細胞診で異型細 胞を認めたが，細胞型は不明であり，確定診断 
Table 1. Reported cases of pulmonary metastasis of intracranial meningioma in Japan.

\begin{tabular}{|c|c|c|c|c|c|c|}
\hline \multirow{2}{*}{$\begin{array}{l}\text { Author } \\
\text { Year }\end{array}$} & \multirow{2}{*}{$\begin{array}{l}\text { Age } \\
\text { Sex }\end{array}$} & \multicolumn{2}{|c|}{ Histology } & \multirow{2}{*}{ Site of Reccurence } & \multirow{2}{*}{ Duration* } & \multirow{2}{*}{ Outcome } \\
\hline & & Primary lesion & Metastatic lesion & & & \\
\hline $\begin{array}{l}\text { Kyohi } \\
1972\end{array}$ & & & & lung,pleura & 3yrs & $\begin{array}{l}\text { unknown, } \\
\text { Dead }\end{array}$ \\
\hline $\begin{array}{l}\text { Akagi } \\
1974\end{array}$ & $\begin{array}{c}33 \\
\text { Female }\end{array}$ & angioblastic & angioblastic & $\begin{array}{l}\text { local,lung,liver, bone } \\
\text { pancreas }\end{array}$ & $\begin{array}{l}6 \mathrm{yrs} \\
9 \mathrm{mos}\end{array}$ & $\begin{array}{l}8 \mathrm{yrs} 6 \mathrm{mos} \\
\text { Dead }\end{array}$ \\
\hline $\begin{array}{l}\text { Utsunomiya } \\
1974\end{array}$ & $\begin{array}{c}33 \\
\text { Female }\end{array}$ & & angioblastic & $\begin{array}{l}\text { lung,bone,liver,brain } \\
\text { pancreas, vertebra }\end{array}$ & $7 \mathrm{yrs}$ & $\begin{array}{l}\text { 9yrs } \\
\text { Dead }\end{array}$ \\
\hline $\begin{array}{l}\text { Ohkuma } \\
1975\end{array}$ & $\begin{array}{c}34 \\
\text { Female }\end{array}$ & $\begin{array}{l}\text { meningothelio- } \\
\text { matous }\end{array}$ & $\begin{array}{l}\text { meningothelio- } \\
\text { matous }\end{array}$ & local,lung & $7 \mathrm{mos}$ & $\begin{array}{l}7 \mathrm{mos} \\
\text { Dead }\end{array}$ \\
\hline $\begin{array}{l}\text { Iwamoto } \\
1977\end{array}$ & $\begin{array}{c}56 \\
\text { Male }\end{array}$ & $\begin{array}{l}\text { meningothelio- } \\
\text { matous(transi- } \\
\text { tional type) }\end{array}$ & $\begin{array}{l}\text { meningothelio - } \\
\text { matous(transi- } \\
\text { tional type) }\end{array}$ & local,lung & $\begin{array}{l}8 \mathrm{yrs} \\
10 \mathrm{mos}\end{array}$ & $\begin{array}{l}\text { 11yrs } 7 \mathrm{mos}, \\
\text { Dead }\end{array}$ \\
\hline $\begin{array}{l}\text { Iwamoto } \\
1977\end{array}$ & $\begin{array}{c}37 \\
\text { Female }\end{array}$ & $\begin{array}{l}\text { hemangioperi- } \\
\text { cytic }\end{array}$ & $\begin{array}{l}\text { hemangioperi- } \\
\text { cytic }\end{array}$ & local,lung & $\begin{array}{l}9 \mathrm{yrs} \\
8 \mathrm{mos}\end{array}$ & $\begin{array}{l}\text { 10yrs } 9 \mathrm{mos}, \\
\text { Alive }\end{array}$ \\
\hline $\begin{array}{l}\text { Hayabuchi } \\
1977\end{array}$ & $\begin{array}{c}35 \\
\text { Male }\end{array}$ & & & local,lung & $5 \mathrm{yrs}$ & unknown \\
\hline $\begin{array}{l}\text { Ueyama } \\
1979\end{array}$ & $\begin{array}{c}43 \\
\text { Male }\end{array}$ & malignant & & $\begin{array}{l}\text { local,lung,liver } \\
\text { adrenal,kidney,bone }\end{array}$ & $\begin{array}{l}3 \mathrm{yrs} \\
2 \mathrm{mos}\end{array}$ & $\begin{array}{l}\text { 3yrs } 2 \mathrm{mos} \\
\text { Dead }\end{array}$ \\
\hline $\begin{array}{l}\text { Matsuno } \\
1980\end{array}$ & $\begin{array}{c}27 \\
\text { Male }\end{array}$ & angioblastic & angioblastic & bone,lung & $7 \mathrm{yrs}$ & $\begin{array}{l}\text { 7yrs, } \\
\text { Alive }\end{array}$ \\
\hline $\begin{array}{l}\text { Kinomoto } \\
1982\end{array}$ & $\begin{array}{c}35 \\
\text { Male }\end{array}$ & angioblastic & angioblastics & local,bone,lung & $\begin{array}{l}\text { 6yrs } \\
3 \mathrm{mos}\end{array}$ & $\begin{array}{l}\text { 9yrs } 6 \mathrm{mos} \\
\text { Alive }\end{array}$ \\
\hline $\begin{array}{l}\text { Ishibashi } \\
1983\end{array}$ & $\begin{array}{c}21 \\
\text { Female }\end{array}$ & fibrobrastic & fibrosarcomatous & local,lung,liver & $\begin{array}{l}1 \mathrm{yrs} \\
9 \mathrm{mos}\end{array}$ & $\begin{array}{l}2 \mathrm{yrs} 5 \mathrm{mos}, \\
\text { Dead }\end{array}$ \\
\hline $\begin{array}{l}\text { Miyamoto } \\
1984\end{array}$ & $\begin{array}{c}44 \\
\text { Male }\end{array}$ & $\begin{array}{l}\text { meningothelio- } \\
\text { matous(syncyti- } \\
\text { al type) }\end{array}$ & fibrosarcomatous & local,lung & $\begin{array}{l}3 \mathrm{yrs} \\
4 \mathrm{mos}\end{array}$ & $\begin{array}{l}\text { 4yrs } 5 \mathrm{mos} \\
\text { Dead }\end{array}$ \\
\hline $\begin{array}{l}\text { Nakamura } \\
1986\end{array}$ & $\begin{array}{c}26 \\
\text { Male }\end{array}$ & angioblastic & angioblastic & local,bone,lung,liver & $\begin{array}{l}9 \mathrm{yrs} \\
6 \mathrm{mos}\end{array}$ & $\begin{array}{l}12 \mathrm{yrs} 4 \mathrm{mos}, \\
\text { Dead }\end{array}$ \\
\hline $\begin{array}{l}\text { Present case } \\
1987\end{array}$ & $\begin{array}{c}42 \\
\text { Female }\end{array}$ & angioblastic & angioblastic & lung & $19 \mathrm{yrs}$ & $\begin{array}{l}\text { 20yrs, } \\
\text { Alive }\end{array}$ \\
\hline
\end{tabular}

のつかないまま開胸， 4 個の腫瘤を摘出した。 術後の病理検査で，血管外皮細胞腫と診断され た.

ところで，血管外皮細胞腫はStoutとMur$\mathrm{ray}^{2}$ により血管腫から独立した腫瘍として定 義され，組織学的には毛細血管とその周囲に外 皮細胞が血管腔を囲んで増殖している像を特徵 としている。多くは筋肉, 皮膚に発生するが, 本症例は同部に明らかな腫瘤を認めず，血管外 皮細胞腫の肺転移とは考えられなかった。また 肺原発の血管外皮細胞腫は極めて稀で，本邦で は1961年貝田ら 3)の報告以来10例に満たず4)，し かもいずれも単発性である。

本症例は19年前ではあるが他院で脳腫瘍の摘 出術を受けていることから当時の組織標本を再 検する機会を得たところ，小脳天幕原発の䯣膜 腫で，大部分fibroblasticで良性と診断されてい
た1). しかしそのごく一部に血管外皮細胞腫様 の組織像が認められ，今回の肺腫瘍の組織像と 極めてよく類似していた. 従って最終的に髄膜 腫の晚期肺転移と診断された極めて稀な1例で ある。

髄膜腫は頭蓋内腫瘍の中では神経膠腫に次い で発生頻度は高いが，生物学的悪性度は比較的 低い。予後は一般に良好とされているが, 局所 再発を繰り返し，周囲頭蓋骨へ浸潤することは 稀ではない。しかし頭蓋外への遠隔転移は稀で あり，その頻度は $0.1 \%$ 年と言われている。転移 臓器としては肺が最も多く, 次いで肝を主体と する腹部藏器, 稀にリンパ節や骨への転移も報 告されている．著者らの知り得た範囲での肺転 移の本邦報告例は自験例を含め14例6) 10)であっ た (Table 1).そこでこの14例を中心に髄膜腫の 肺転移につき検討を加えた。 
年齢，性：一般に髄膜腫は40歳代に好発し， 男性に比べ女性に約 2 倍の頻度で発生すると言 われている。一方肺転移症例の平均年齢は35歳 で若年者程悪性化が強いという傾向と一致して いる。性別では男性 7 , 女性 6 , 不明 1 とやや 男性に多い. 木野本ら ${ }^{8)}$ の頭蓋外転移 71 症例の 検討で毛男性 38 , 女性 25 , 不明 8 と通常の発生 頻度と異なり，やや男性に多く，悪性度と性別 に何らかの関係があるのかも知れない。

発生部位及び手術根治度：髄膜腫の好発部位 としては傍矢状洞，弓隆，鞍結節，蝶形骨稜の 順に多いとされている。一方肺転移症例のうち 記載の明らかなものの原発巣をみると傍矢状洞 5 例, 小脳天幕 4 例, 弓隆 2 例, 斜台部 1 例で ある。頭蓋外転移経路として開頭術時に腫瘍細 胞が静脈系に侵大することがありうるが， Rubinstein ${ }^{11)}$ はそのよjな可能性はあまりない と述べている。しかし，大動脈系に接する傍矢 状洞にもともと発生頻度が高く，肺転移が多い ことは注目する必要がある。

またSimpson ${ }^{12)} ら は$ 手術根治度が再発, 転移 の重要な因子であると述べている. 小脳天幕, 斜台部の髄膜腫は解剖学的位置関係より手術操 作が困難で, 不完全摘出に終る可能性が強い. 比較的発生頻度の少ないこの部からの肺転移が 多いのは，手術根治性の低さが理由であろう。 肺転移14症例の手術根治度を見ると明らかに部 分切除に終った 1 例を除き，他はすべて肉眼的 に腫瘍は摘出 (傍矢状洞の 2 例は付着部を電気 凝固)されているが, Simpsonの根治度 (I 〜 V $)^{12)}$ による明確な記載はない. 自験例を除く 全症例がその後の経過で局所再発が確認され, 内 6 例は再度開頭術が行われている。手術根治 性の低さが頭蓋外転移の最大の原因と考えられ る.

組織型：14症例の原発巣の組織型をみると angioblastic 5 例, fibroblastic 2 例, meningotheliomatous 3 例, malignant meningioma 1 例, 不明 3 例である。一方肺転移巣の組織型 はfibroblastic, meningotheliomatous $の$ 各 1 例 が fibrosarcomaに, 自験例の fibroblastic が angioblasticと変わった以外, 原発巣の組織型
と同様であった，組織型と再発，転移に関して は諸論があり99,13)必ずしも一致していない点も あるが, angioblastic特に hemangiopericytic typeに遠隔転移が多いという事は確実である。 再発, 転移巣の組織像は一般に異型度の増強像 を示し，これを腫痬細胞の悪性変化に求める意 見もあるが, 自験例から明らかな様に, 大部分 fibroblasticではあるが詳細にみるとごく一部 にangioblasticな部分が原発巣に認められ, 潜 在的悪性度のより強い腫瘍組織部分からの再発 転移が起る可能性が強いと考えた方が妥当のよ うに思われる。

肺転移までの期間：最少 7 力月から最大 19 年 で平均 6.6 年と, 原発巣初回治療からの期間は一 般に転移性肺腫瘍が術後 2 - 3 年に起こるのと 比べ晚期転移が多い. しかし個々の症例の経過 を詳しくみると晚期肺転移例9),10)であっても， 骨転移や局所再発が先行したり，剖検で脳局所 再発が確認される例がほとんどで, 初回手術以 後の経過で肺転移が二次的に起こったと考える と他の転移性肺腫痬と同様で, 必ずしも発育が 著しく遅いとは言えない。しかし自験例は現在 画像診断上でも局所や他に再発を認めず，初回 手術時又はそれ以前に肺転移巣が形成されたと 考えざるを得ない。

(1)19年間の長期にわたり極めて徐々に発育し たものか, (2)dormantな状態の細胞が宿主の免 疫能の変化によりある時期より増大を始めたか は極めて興味があるが，過去に胸部X線撮影を 受けていないため明らかでない。しかし乳癌手 術後胸部 X 線で異常ない症例が10年以後に突然 肺転移が明らかとなる症例があることを考える と, 後者の可能性が高い様に思われる.

肺転移巣の治療：肺転移巣以外に再発, 転移 のみられる症例が多いことや，肺転移巣が多発 しているため, 肺転移巣の切除は自験例を含め 3 例7),10)にすぎず，そのうち 1 例は術後肝転移 で死亡している．従って本症例も今後肝を中心 とする再発に注意する必要があろう。一般に髄 膜腫の局所再発，転移症例には放射線療法がよ

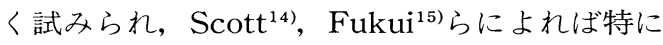
angioblastic typeに感受性が高いと報告してい 
る。確かに肺転移巣に対して放射線治療が行わ れた中で，有効，著効例はすべて angioblastic typeであり，摘出不能の本組織型に対しては放 射線治療により延命を計るべく試みる価值があ ろう.
謝 辞

この報告にあたって, 貴重な資料を御提供下さった大 阪赤十字病院脳神経外科部長, 安藤協三先生ならびに松 島医院，松島正之先生に深謝いたします。
1) Wage, S., Matsuda, M., Handa, H., et al. : Multiple meningiomas Report of four cases. J. Neurosurg., 37 : 348-351, 1972.

2) Stout, A.P. \& Murray, M.R. : Hemangiopericytoma. Ann. Surg., $116: 26,1942$.

3）貝田勝美, 田中健蔵, 新開貫生：肺に原発した 血管周皮細胞腫の 1 切除例. 日胸, $20: 39-42$, 1961.

4）川本俊弘, 吉川尚孝, 平賀 隆：肺原発の血管 外皮細胞腫の 1 例. 日胸, 42：60-65，1983.

5) Strang, R.R., Tovi, D., Nordenstam, H. : Meningioma with intracerebral, cerebellar and visceral metastases. J. Neurosurg., $21:$ 1098-1102, 1964.

6）松野丈夫，石井清一，金田清志，他：骨転移を きたしたAngioblastic meningiomaの 2 例. 北 海道整形災害外科雑誌， $25 ： 70-77,1980$.

7) 石橋安彦, 岡田 仁, 森 照明, 他：頭蓋外多 発転移を生じた再発meningiomaの 1 例。脳神 経外科, 11：203-208，1983.

8）木野本均, 岩崎喜信, 中川 翼, 他：髄膜腫の 頭蓋外転移。脳神経外科, $10 ： 319-326,1982$.

9）宮本康文, 可部順三郎, 野田栄次郎, 他：肺一 の転移を来したmalignant meningiomaの 1 例. 呼吸, 3 :285-289, 1984.
10）岩本亜彦，鈴木陽一，鳴尾好人，他：肺転移を 認めた meningiomaの 2 症例. 日外宝, 46 ： 499, 1977.

11) Rubinstein, L.J. : Tumor of the central nervous system. Atlas of Tumor Pathology, 2nd Series, Fascicle 6, Armed Forces Institute of Pathology, Washington, p187, 1972.

12) Simpson, D. : The recurrence of intracranial meningiomas after surgical treatment. J. Neurol. Neurosurg. Psychiatr., 20:22-39, 1957.

13）田村 勝, 川淵純一, 井上 洋, 他：䯣膜腫の 術後遠隔成績一腫瘍覀性変化と再発の関連性 についてー. Neurol. Med. Chir. (Tokyo), 19: 411-419, 1979.

14) Scott, M., Kellet, G., Peale, A. : Angioblastic meningioma (hemangiopericytoma) of the cerebellar fossa with metastases to the temporal bone and the lumbar spine. Surg. Neurol., 2 : 35-38, 1974.

15) Fukui, M., Shima, F., Abe, M., et al. : Recurrent intracranial meningioma with metastasis in the skull. A case report. Neurol. Med. Chir. (Tokyo), $20: 107-111,1980$. 


\title{
Late Pulmonary Metastases of Cerebellar Meningioma - A Case Report
}

\author{
Akitaka Ogawa ${ }^{1)}$, Osamu Doi ${ }^{1)}$, Ken Kodama ${ }^{1)}$, \\ Masayuki Tatuta'), Takesi Hourai ${ }^{2}$ and Ryuhei Tateisi ${ }^{3)}$ \\ Department of Surgery ${ }^{1)}$, Internal Medicine ${ }^{2)}$ and Pathology3), \\ The Center for Adult Diseases, Osaka
}

A 61-year-old female, who had undergone craniotomy for benign multiple cerebellar meningioma 19 years ago, came to our hospital with a complaint of chest pain. Her chest roentgenogram showed three mass shadows which involved bilateral lungs. Through bilateral thoracotomy by median sternotomy, four lung tumors were removed, which revealed same histological pattern and were diagnosed as hemangiopericytoma.

Fortunately, the histological specimens and detailed data of her cerebellar meningioma were obtained, and it was elucidated that the small angioblastic portion in the fibroblastic meningioma metastasized to the lungs.

Thirteen cases of intracranial meningioma associated with lung metastases have been reported in the literature so far in Japan, and successful removal of such metastases as this case was not recorded. 